\title{
Immunolocalization of 91 kDa Ascitic Protein in the Human Placenta
}

\author{
By \\ Koji KAMI $^{1)}$, Noriaki SATO' ${ }^{1)}$, Toshiyuki MORITA ${ }^{1)}$, Isamu ISHIWATA ${ }^{2)}$, \\ Masakazu ISHIKAWA ${ }^{3)}$ and Mitsuo NAKAI ${ }^{3)}$
Department of Human Morphology and Physiology, Tokiwa University School of Human Sciences 1), 1-430-1 Miwa, Mito 310; Ishiwata Obstetrics and Gynaecology Hospital ${ }^{2}$, 1-4-21 Kami-Mito, Mito 310; Department of Obstetrics and Gynaecology, Kitasato University School of Medicine ${ }^{3)}$, 1-15-1 Kitasato, Sagamihara 228, Japan

- Received for Publication, September 29, $1995-$

\begin{abstract}
Key Words: $91 \mathrm{kDa}$ Ascitic protein, Hofbauer cell, Human placenta, Immunocytochemistry, Placental barrier, Transplacental permeability

Summary: A $91 \mathrm{kDa}$ protein, sharing antigenicity with a pregnancy-associated antigen, was isolated from the ascitic fluid of a patient suffered from the gynaecological malignant neoplasms. It was revealed in the human placenta by immunocytochemical techniques, and found to be localized in the stroma, including a fibrous network, fibroblasts and the Hofbauer cells of the terminal and stem villi in the first trimester. Immunoreactive staining was also found in macrophage-like cells, presumable the precursor of the Hofbauer cell, in the stem villi of placenta. It is assumed that macrophage-like cells containing the protein would be originated from the extraembryonic mesoderm or blood vessels, and then migrated to the stroma of terminal villi. During the second trimester, the protein was observed in numerous vesicles among the syncytial trophoblasts. The density of these immunoreactive vesicles and the cytoplasm of Hofbauer cells was rapidly increased with gestational stages, whereas it was gradually reduced towards the late-second trimester. The highest labellings occurred at around 17 weeks or later. On the other hand, at term, the protein was mainly observed in numerous villous blood vessels including endothelial cells. In the light of these results, a hypothesis concerning mechanisms of transplacental permeability of the protein by the placental barrier is discussed further.
\end{abstract}

The morphogenesis of both foetuses and neoplasms is accompanied by the ontogeneticallyprogrammed appearance and disappearance of several proteins including enzymes. These proteins have been shown to be related to embryonic developments and oncopathological statuses.

On the other hand, in clinical evidences, the placentological light of these proteins is also focussed on characteristics of the phenemena in relation to pregnancies and malignancies. ${ }^{14,32)}$ So far, a numerous placental protein; such as hCG-A and $\mathrm{B}^{4,18,31)}$, hPL ${ }^{11,12)}$, PAPP-A and $\mathrm{B}^{16,17,28,33)}$, $\mathrm{PP}_{1 \sim 16}{ }^{6,7,8,27,29)}, \mathrm{SP}_{1 \sim 3}{ }^{7,8,30)}, \mathrm{CA} 125^{3)}$ and $\mathrm{Ca}$ $19-9^{3)}$, were involved in oncodevelopmental aspects at cellular and molecular levels. However, they seemed to be limited to the clinical usefulness. ${ }^{1,3,5,15}$

In recent years, a novel $94 \mathrm{kDa}$ pregnancyassociated protein isolated from the placenta has been extensively studied from a variety of aspects. ${ }^{19,20,24)}$ There is a body of evidence showing that an alpha 2 -protein of the placenta exists to be identical with the protein obtained from malignant ascitic fluids of a patient with the advanced ovarian cancer ${ }^{22,23)}$, whereas a molecular size is found to be $91 \mathrm{k}$ daltons by SDS-PAGE procedures. ${ }^{25)}$ Moreover, it is assumed that the protein would play important roles in both tumour-associated statues and pregnancy-associated evidences. ${ }^{26)}$

To date, however, nothing is known about the microscopical distribution of the protein in the human placenta and neoplasm. The aim of this study was to address questions of where $91 \mathrm{kDa}$ ascitic protein is localized in the placenta using an immunocytochemical technique. A part of this study was presented in the 9th International Congress of Histochemistry and Cytochemistry, at Maastricht, The Netherlands. ${ }^{10)}$

\section{Materials and Methods}

\section{Chemicals}

Biotin-labelled goat anti-rabbit IgG, avidin-biotinhorseradish peroxidase (HRP) complex and avidin- 
biotin-Fluorescein (FITC) complex were obtained from Vector Laboratories (Ca., U.S.A.). 3,3'Diaminobenzidine tetrahydrochloride (DAB) was purchased from Dojin Chemicals (Kumamoto, Japan).

Preparation of $91 \mathrm{kDa}$ ascitic protein and its antibody

Ascitic fluid used was obtained from a patient with a malignant ovarian and uterine tumour (mixed mesodermal tumour) at the time of paracentesis, and then centrifuged at $5,000 \mathrm{rpm}$ for $30 \mathrm{~min}$ at $4^{\circ} \mathrm{C}$. The supernatant was kept at $-20^{\circ} \mathrm{C}$ until use.

An ectopic developmental antigen that appears in malignant ascitic fluid was separated by a new procedure involving DEAE-Sepharose chromatography as described in the previous paper. ${ }^{25)}$ In brief, pooled ascitic fluid was treated as follow: (1) immunoglobulins were removed using polyethylene glycol 4,000 fractionation; (2) the peak, on DEAESepharose chromatography at $\mathrm{pH} 6.6$, showing the highest specific reactivity to the "First-Generation" antiserum $^{21) 22}$ ) was collected; (3) the protein was separated by a preparative-polyacrylamide gel electrophoresis (PAGE); (4) the antibody against the protein was generated in rabbits; (5) the antibody was applied to a column of normal human plasma (NHP)-coupled Sepharose 4B, then, the "SecondGeneration" antibody was obtained within the unbound fractions; (6) a molecular size of the protein was confirmed to be $91 \mathrm{kDa}$ by SDS-PAGE; (7) the monospecificity of the antibody was found using a SDS-PAGE-'SRID' technique.

In this study, the antibody obtained was used for revealing immunocytochemical characterization of the protein in the human placenta.

\section{Tissue preparation}

Thirty-eight placentas were obtained from healthy women at between the 7 th and 42 nd week of gestation (14 at 7 10 weeks; 15 at $11 \sim 20$ weeks; 9 at $37 \sim 42$ weeks at term). Small pieces $\left(1 \mathrm{~mm}^{3}\right)$ of villous tissue were excised and fixed by immersion at $4^{\circ} \mathrm{C}$ for $4 \sim 6 \mathrm{~h}$ in Zamboni's fixative with a minor modification $^{9,34)}$, and then processed through graded changes of ethanol and xylene, and embedded in paraffin wax.

\section{Immunocytochemical procedures}

All immunocytochemical procedures were carried out at room temperature. Deparaffinized sections kept in $0.01 \mathrm{M}$ phosphate-buffered saline (PBS), $\mathrm{pH}$ 7.3, were subjected to the following protocol: (1) enzymatic digestion with $0.1 \%(\mathrm{w} / \mathrm{v})$ pepsin in $0.05 \mathrm{M}$ Tris- $\mathrm{HCl}$ buffer, $\mathrm{pH} 7.6$, containing $0.1 \%(\mathrm{w} / \mathrm{v})$ $\mathrm{CaCl}_{2}, 30 \mathrm{~min}$ at $37^{\circ} \mathrm{C}$; (2) 3 washes with PBS, 5 min each; (3) blocking of endogenous peroxidase activity with $5 \mathrm{mM}$ sodium metaperiodate solution, $10 \mathrm{~min}$; (4) 3 washes with PBS, 5 min each; (5) blocking freealdehyde groups with $3 \mathrm{mM}$ sodium borohydride solution, $10 \mathrm{~min}$; (6) 3 washes with PBS, 5 min each; (7) pre-treatment with highly diluted $(1: 2,500)$ normal goat serum, $30 \mathrm{~min}$; (8) incubation with the specific antibody diluted at $1: 400$ to $1: 2,000$ with PBSA (PBS containing $0.5 \%$ bovine serum albumin), 2 4h; (9) 3 washes with PBS, 10 min each; (10) incubation with biotin-labelled goat anti-rabbit IgG, $30 \mathrm{~min}$; (11) 3 washes with PBS, $10 \mathrm{~min}$ each; (12) incubation with avidin-biotin-HRP complex, $30 \mathrm{~min}$; (13) 3 washes with PBS, 10 min each.

In the final step, sections were incubated for

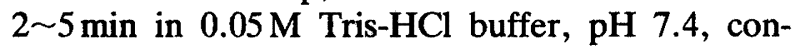
taining $0.02 \%(\mathrm{w} / \mathrm{v}) \quad 3,3^{\prime}$-diaminobenzidine tetrahydrochloride and $0.001 \%(\mathrm{v} / \mathrm{v})$ hydrogen peroxide, and counterstained with $0.1 \%$ (w/v) Methyl Green in barbitone buffer at $\mathrm{pH} 4.0$ for $1 \mathrm{~h}$ or with Mayer's Haematoxylin for $10 \mathrm{~min}$.

Immunofluorescence antibody procedures followed the above-described protocol except that avidinbiotin-HRP complex was substituted with avidinbiotin-FITC complex.

In order to confirm the specificity of labellings, two concurrent control experiments were performed: (a) preimmune rabbit serum used in place of the specific antibody, and (b) avidin-biotin-HRP complex or avidin-biotin-FITC complex alone, omitting biotin-labelled goat anti-rabbit IgG to identify any non-specific adsorption of the complex.

\section{Results}

Human placentae subjected are divided into three groups by their gestational periods; the first $(7 \sim 10$ weeks), second (11 20 weeks) and third (term) trimesters. Figures $1 \sim 3$ and Table 1 are representative of immunomicroscopical stainings most commonly seen in human placental tissues and their summarized conclusions, respectively. In the control experiments, a specific staining was never observed when a preimmune rabbit serum was used. Neither endogenous peroxidase activity nor autofluorescence was detected.

In the first trimester, the affinity-purified antibody frequently exhibited specific immunostainings to be in close association with stroma of the secondary and tertiary villi; fibrous networks, fibroblasts and the Hofbauer cells (Figs. 1-A 1-C). The distribution of immunoreactive terminal villi was not uniform; some were positive whereas the rests were negative. Labellings in villous stroma were completely disappeared during the second trimester. A few immunogenic dot-structures were also simultaneously localized near apical regions of syncytiotrophoblasts. 
Table 1. Reactivity of anti-91 kDa ascitic protein antibody in the human placenta

\begin{tabular}{|c|c|c|c|c|c|}
\hline & \multicolumn{4}{|c|}{ Gestational period } & \multirow[b]{2}{*}{3 rd } \\
\hline & \multirow{3}{*}{$\frac{1 \mathrm{st}}{\text { trimester }}$} & \multicolumn{3}{|c|}{ 2nd trimester } & \\
\hline & & early & mid & late & trimester \\
\hline & & & & & (at term) \\
\hline Fibrous network of the terminal villi & +++ & ++ & + & 0 & $\mathbf{0}$ \\
\hline Fibroblasts & ++ & + & + & 0 & 0 \\
\hline Hofbauer cells & +++ & +++ & ++ & + & 0 \\
\hline Vesicular contents of syncytiotrophoblasts & + & ++ & +++ & + & \pm \\
\hline Langhan's cells & 0 & 0 & 0 & 0 & 0 \\
\hline Villous blood vessels & 0 & 0 & + & ++ & +++ \\
\hline Macrophage-like cells of the stem villi & +++ & * & $*$ & $*$ & * \\
\hline Basement membrane & 0 & 0 & + & + & 0 \\
\hline
\end{tabular}

+++ :very strong staining; ++:moderate staining; +:weak staining; \pm :very weak staining; 0:no staining; Astarisks (*) indicate no tissue examined.

The population of these structures gradually increased as gestation progressed. In contrast, immunoreactive evidences were recognized in macrophage-like cells of the stroma in the secondary and tertiary stem chorionic villi (Fig. 1-D). So far, however, the immunostaining was never seen in the umbilical cord.

In the second trimester, immunostainings were demonstrated within a numerous vesicle located in the apical part of syncytiotrophoblasts, although no evidence was seen in the cytotrophoblast (Figs. $2-A \sim 2-E)$. The content of immunoreactive vesicles rapidly increased with gestational stages, reaching a maximum around 17 weeks, and then gradually reduced towards a term. The foetal blood vessel also showed positive reactions during the later-half of the second trimester; the lumen of blood vessels and endothelial cells (Figs. 2-C and 2-D). Occasionally, around the latter half of the second trimester, a small number of dot-structures which presented by an immunofluorescence technique were associated with the basement membrane (Fig. 2-F).

At term, the major localization of the protein was shown in the foetal blood vessels including endothelial cells (Figs. 3-A $\sim 3-D$ ). Intensity of the immunostaining was distinctly higher than that obtained in the second trimester. In contrast, a very few dot-structures demonstrated by immunostainings were only just detected in epithelial folds faced to the maternal space of flattened syncytiotrophoblasts.

\section{Discussion}

A novel pregnancy-associated protein with a mol- ecular size of $94 \mathrm{k}$ daltons is originally separated from the human placenta at term. Subsequently, the "First-Generation" antibody against the protein reveals a existence of the antigenic molecular mass in the sera of pregnant women and ascitic fluids of patients with advanced ovarian cancer using immunological techniques. ${ }^{20,22,23,24)}$ In recent years, an ectopic ascitic protein is purified by a new procedure using

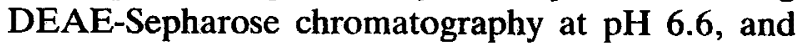
its molecular size is determined to be about $91 \mathrm{k}$ daltons. ${ }^{25)}$ Furthermore, the "Second-Generation" antibody shows to be useful to semi-quantitative measurements; a higher serum concentration in pregnant women than that estimated in regularmenstrating women, or much higher levels in ascitic fluids of patients with malignant diseases than that of the health, respectively. ${ }^{26)}$

The aim of this study was to determine an immunocytochemical characterization of the ectopic antigen in the human placenta using the same antibody against $91 \mathrm{kDa}$ protein. ${ }^{25}$ ) As a result, there are marked differences on the localization of the protein in parallel with gestational stages.

In the first trimester, the antigenic localization was detected to be predominantly limited in the foetal stromal tissue elements of terminal villi including fibroblasts and the Hofbauer cells. In early stage of placentation, it is well known that the basic tissue-skeleton in the stroma of chorionic villi should be derived from the extraembryonic mesodermal cells. ${ }^{13)}$ The present results are supplemented by the finding that immunoreactive macrophage-like cell populations in the stem villi can be detected. Although the definite cellular classification of these mesodermal cells is still unanswered, it is reasonable to 
suppose that the presumable precursor cells should originate from the connective tissue or blood vessels of the stem villi, migrate to the fibrous network of terminal villi and, in this special microenvironment of placentation in the 1st trimester, differentiate into the participant cells which could supply physiological materials programmed.

During the second trimester, the present data clearly demonstrates that a numerous small vesicle with antigenicity were determined in the apical part of syncytiotrophoblasts. The Hofbauer cell represents as an immunoreactive cell population. However, these vesicles of trophoblastic layers and cytoplasmic contents of the Hofbauer cell rapidly reduced by the end of the second trimester. On the contrary, during the course of placentation, the protein is simultaneously characterized by increased accumulation in villous capillaries. Occasionally, immunostainings of dot-structures localized along the basement membrane could be detected. It is postulated that a dynamic permeable transportation of the protein should happen across the membrane until the physiological maturation of placental barrier. This is supported by facts of a high level of the protein found in the maternal blood during the second trimester. ${ }^{23,24,26)}$

At term, the protein is predominantly observed in the villous blood vessels including endothelial cells. This may be reflected that transplacental permeability of the protein to the maternal blood was resisted by the placental barrier in the later-half period of second trimester. ${ }^{2,23)}$ It is worth mentioning as a hypothesis that $91 \mathrm{kDa}$ ascitic protein would be a strong candidate of the marker for characterizing the maturity of villous stroma and placental barrier.

So far, however, little is known of the genuine source of this protein. One would expect the protein should be derived from the extraembryonic mesodermal cells of the stem villi during early-placentation stages. However, further detailed studies are needed in order to obtain precise data in relation to the immunoreactive body which was detected in the foetoplacental circulation at term. Studies with an ultramicroscopical characterization using immunocytochemical techniques are now in progress.

\section{Acknowledgements}

This work was supported in part by a Grant-inAid from the Ministry of Education, Science, Sports and Culture, the Japanese Government (No. 07671818), and by Research Funds from Tokiwa University $(1992,1994)$ and Kitasato University. We wish to thank Professor Dr P. J. Stoward, Department of Anatomy and Physiology, University of
Dundee, Scotland, U.K., for his valuable criticism and commenting on the English manuscript.

\section{References}

1) Bast RC Jr, Feeney M, Lazarus H, Nadler LM, Colvin RB and Knapp RC. Reactivity of a monoclonal antibody with human ovarian cartinoma. J Clin Invest 1981; 68: $1331-1337$.

2) Faber JJ and Thornburg KL. Permeability of the placental membrane for hydrophilic substances. In: Placental Physiology, pp. 79-89, New York: Raven Press, 1983.

3) Gadducci A, Ferdeghini M, Ceccarini T, Prontera C, Facchini V, Bianchi R and Fioretti P. A comparative evaluation of the ability of serum CA 125 , CA 19-9, CA 15-3, CA 50, CA 72-4 and TATI assays in reflecting the course of disease in patients with ovarian cartinoma. Eur J Gynaecol Oncol 1990; 11:127-133.

4) Hoshina M. Cytological localization of chorionic gonadotropin-alpha and placental lactogen mRNA during development of the human placenta. Placenta 1983; 93:190-197, 97:1200-1206.

5) Hoskins WJ, Burke TW and Barnhill DR. Tumor-related antigens in gynecologic cancers: In: Tumor markers and tumor-associated antigens, pp. 149-172, New York: McGraw-Hill Inc., 1987.

6) Inaba $N$, Renk $T$ and Bohn $H$. Immunohistochemical location of new placental proteins $\left(\mathrm{PP}_{8}, \mathrm{PP}_{9}, \mathrm{PP}_{10}, \mathrm{PP}_{11}\right.$, $\mathrm{PP}_{12}$ ) in human placentae. Arch Gynecol 1980; 230: 109-121.

7) Inaba $N$, Renk $T$, Wolfgang $A$, Schottler $S$ and Weinmann E. Possible synthesis of pregnancy-specific beta -glycoprotein $_{1}$ $\left(\mathrm{SP}_{1}\right)$ and placenta-specific tissue proteins $\left(\mathrm{PP}_{10}\right.$ and $\left.\mathrm{PP}_{12}\right)$ by human and cynomolgus monkey (Macaca fascicularis) leukocytes. Acta Haematol 1981a; 66:35-38.

8) Inaba $\mathrm{N}$, Renk $\mathrm{T}$, Weinmann $\mathrm{E}$ and Bohn $\mathrm{H}$. Immunohistochemical location of proteins related to pregnancy-specific beta ${ }_{1}$-glycoprotein $\left(\mathrm{SP}_{1}\right)$ and placental tissue proteins $\left(\mathrm{PP}_{5}\right.$, $\left.\mathbf{P P}_{8}, \mathbf{P P}_{9}, \mathbf{P P}_{10}, \mathbf{P P}_{11}, \mathbf{P P}_{12}\right)$ in the afterbirth of cynomolgus monkey (Macaca fascicularis). Arch Gynecol 1981b; 230: 195-204.

9) Kami K and Stoward PJ. Secretory pathway of vitellogenesis in the liver of the cockerel as revealed by immunogold and computer-assisted digitization techniques. Histochem J 1991; 23:259-266.

10) Kami K, Sato N, Ishikawa $M$ and Nakai $M$. Ontogenetic changes of the localization of tumor-associated 27k-Da protein in the human placenta as revealed by the immunomicroscopical technique. Histochem J 1992; 24:538.

11) Kasai $\mathrm{K}$, Aochi $\mathbf{H}$ and Yoshida $Y$. Production and localization of human prolactin in human chorionic tissue and decidua. Acta Histochem Cytochem 1980; 13:449-454.

12) Kasai K, Shik SS, Aochi $H$ and Yoshida $Y$. Production and localization of human prolactin in the placental and decidual tissue at term. Acta Histochem Cytochem 1981; 14: $168-172$.

13) Kaufmann P. Development and differentiation of the human placental villous tree. Bibl Anat 1982; 22:29-39.

14) Klopper A and Chard T. In: Placental proteins, Berlin: Springer Verlag, 1979.

15) Koprowski H, Herlyn M, Steplewski Z and Sears HF. Specific antigen in serum of patients with colon cartinoma. Science 1981; 212:53-55.

16) Lin TH and Halbert SP. Placental localization of human pregnancy-associated plasma proteins. Science 1976; 193: 
$1249-1252$.

17) Lin TH, Halbert SP and Spellacy WN. Pregnancy-associated plasma protein B (PAPP-B) in normal and abnormal pregnancies at term. Br J Obstet Gynaecol 1978; 85:652-656.

18) Morrish DW, Marusyk $\mathrm{H}$ and Siy O. Demonstration of specific secretory granules for human chorionic gonadotropin in placenta. J Histochem Cytochem 1987; 35:93-101.

19) Nakai M, Atsumi $M$, Majima $T$ and Arai $M$. Presence of a "beta-pregnancy-associated protein" in the human placenta and its value in clinical application. Kitasato Med (in Japanese) 1981; 11:668-678.

20) Nakai $M$, Majima $T$, Atsumi $M$ and Arai $M$. Detection of a pregnancy-associated protein. Eur J Obstet Gynecol Reprod Biol 1985; 20:275-288.

21) Nakai $M$, Atsumi $M$ and Arai $M$. Measurement of the alpha $_{2}$-component of a novel oncodevelopmental antigen by a rapid electroimmunoassay. J Immunol Methods 1987a; 103:179-184.

22) Nakai $M$, Ohsawa $Y$, Nagata $E$ and Arai $M$. An ovarian cancer-associated antigen that crossreacts with a pregnancyassociated protein. Eur J Obstet Gynecol Reprod Biol 1987b; 24:39-48.

23) Nakai $M$, Atsumi $M$, Odagiri $J$ and Arai $M$. Quantitative analysis of a novel pregnancy-associated protein in trophoblastic diseases, normal pregnancy and healthy female subjects. Arch Gynecol Obstet 1988; 243:107-110.

24) Nakai $M$, Atsumi $M$, Sone $Y$ and Arai $M$. Quantitative estimation of an alpha ${ }_{2}$ pregnancy-associated protein in normal pregnancy by electroimmunoassay. Clin Chim Acta 1989; 182:103-108.

25) Nakai $M$, Ishikawa $M$ and Kawauchi $H$. Identification of an ectopic developmental antigen that appears in malignant ascitic fluid. Eur J Obstet Gynecol Reprod Biol 1991; 42: 61-69.

26) Nakai $\mathbf{N}$, Kawauchi $\mathrm{H}$, Atsumi $M$, Majima $T$ and Ishikawa
M. A novel tumor-associated protein: Clinical significance of serum levels in various clinical conditions with special reference to gynecological malignant diseases. Eur J Obstet Gynecol Reprod Biol 1992; 43:143-147.

27) Nito $A$, Inaba $N$, Fukazawa $I$, Ishige $H$, Takamizawa $H$, Luben $G$ and Bohn $H$. Immunoradiometrical and histochemical investigation of placenta-"specific" tissue protein 5,10 and $11\left(\mathrm{PP}_{5,10}\right.$ and 11$)$ in normal pregnancy and ovarian cystadenocarcinoma. Chiba Med J 1986; 62:143-152.

28) Schindler AM. Immunohistochemical localization of pregnancy-associated plasma protein-A (PAPP-A) in decidua and trophoblast. Comparison with hCG and fibrin. Placenta 1984; 5:227-236.

29) Sedlacek HH. Immunofluorescence histological localization of human pregnancy and placenta proteins in the placenta of man and monkey (Cynomolgus). Behring Inst Mitt 1976; 69:81-91.

30) Smith $R$, Highes $G$ and Wilson $G$. The compartmental distribution of estrogens and pregnancy specific beta $\mathrm{I}_{1}$ - glycoprotein. Br J Obstet Gynaecol 1979; 86:119-124.

31) Suemizu H, Osamura $Y$ and Watanabe K. Ultrastructural localization of HCG and subunits in the human placenta and choriocartinoma cell lines-morphological approach to secretory pathway. Acta Histochem Cytochem 1988; 21: 265-271.

32) Takagi $S$, Sugawa $T$, Ichijo $M$ and Mizuno $M$. In: The Placenta; Structure and function, ("Taiban; Kiso To Rinshow", in Japanese) Tokyo: Nankodo Co. Ltd., 1991.

33) Wahlstrom T, Teisner B and Folkerson J. Tissue localization of pregnancy-associated plasma protein-A (PAPP-A) in normal placenta. Placenta 1981; 2:253-258.

34) Zamboni L and De Martino C. Buffered picric acidformaldehyde. A new rapid fixation for electron microscopy. J Cell Biol 1967; 35:148A. 
Plate I
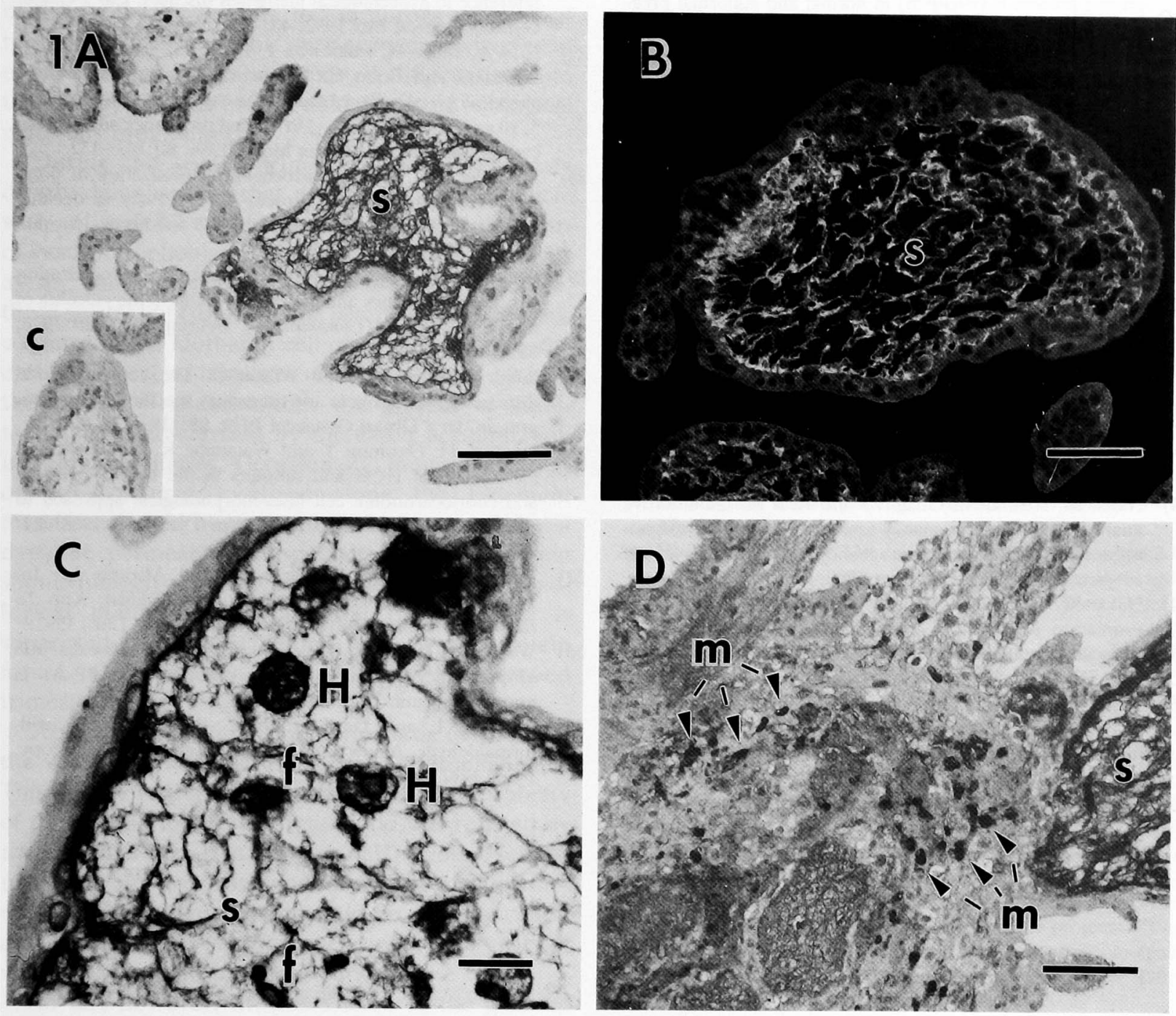

\section{Explanation of Figures}

\section{Plate I}

Fig. 1. Immunocytochemical staining of the villi in the first-trimester. A: Fibrous stroma (s). $\times 300$. Bar $=50 \mu \mathrm{m}$. Negative control (c). $\times 220$. Age; 8 weeks and 6 days. Methyl Green counterstain. B: Fibrous stroma (s). Age; 12 weeks. $\times 300$. Bar $=50 \mu \mathrm{m}$. C: Hofbauer cells (H), fibroblasts (f), fibrous stroma (s). Age; 12 weeks. $\times 1,200$. Mayer's Haematoxylin counterstain. Bar $=$ $10 \mu \mathrm{m}$. D: Macrophage-like cells (m) of the tertiary stem villi. Fibrous stroma (s). Age; 7 weeks and 3 days. $\times 300$. Methyl Green counterstain. Bar $=50 \mu \mathrm{m}$. 

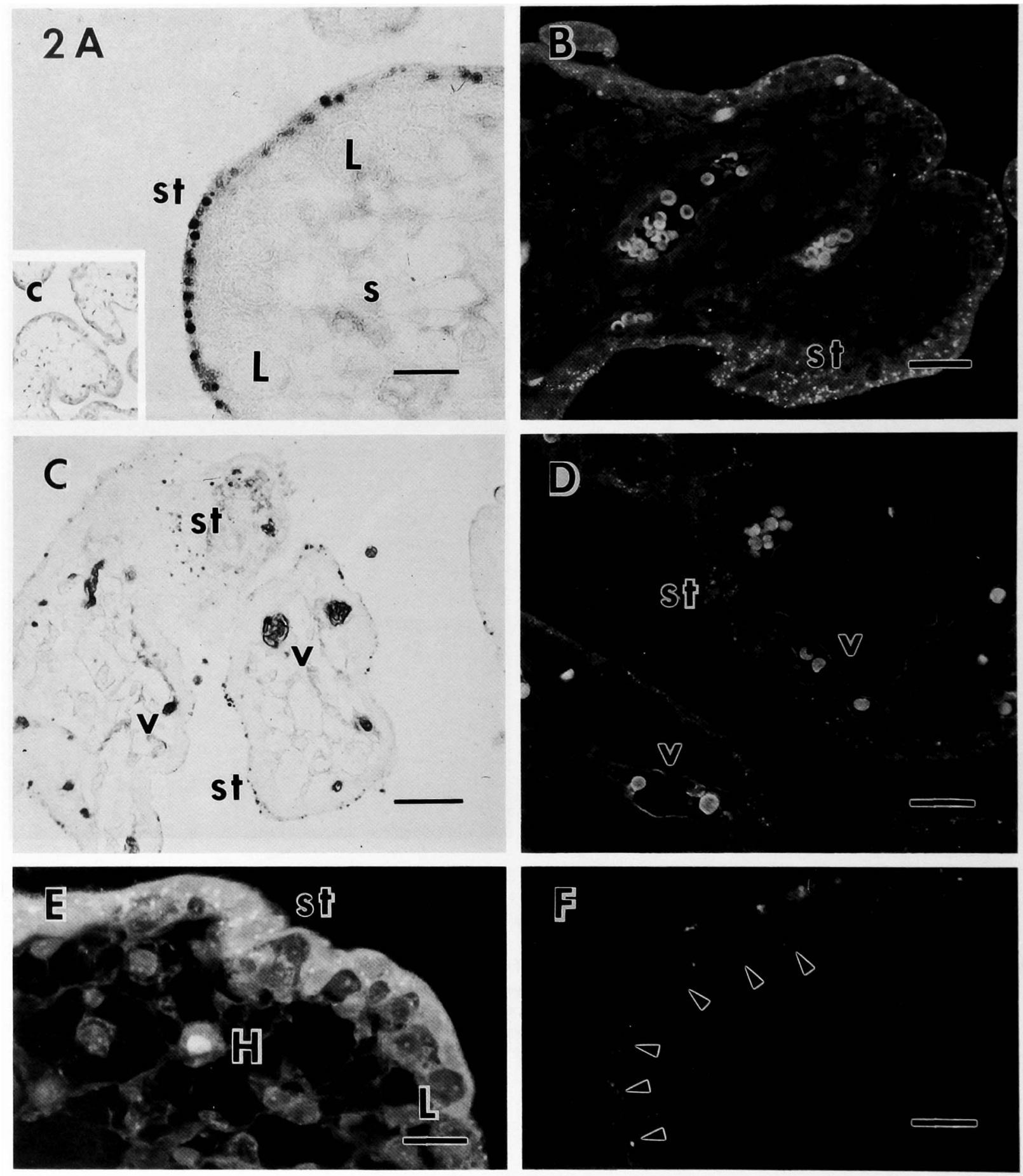

Plate II

Fig. 2. Immunocytochemical staining of the villi in the second-trimester. A: Vesicular stainings in the syncytial trophoblasts (st). Langhan's cells (L), fibrous stroma (s). $\times 1,200$. Bar $=10 \mu \mathrm{m}$; Negative control (c). Age: 17 weeks. $\times 220$. Methyl Green counterstain. B: Vesicular fluorescence in the syncytial trophoblasts (st). Age; 17 weeks. $\times 600$. Bar $=20 \mu \mathrm{m}$. C: Syncytila trophoblasts (st), foetal blood vessels (v). Age: 17 weeks. $\times 600$. Methyl Green counterstain. Bar $=20 \mu \mathrm{m}$. D: Syncytial trophoblasts (st), foetal blood vessels (v). Age; 19 weeks and 6 days. $\times 600$. Bar $=20 \mu \mathrm{m}$. E: Hofbauer cells (H), syncytial trophoblasts (st), Langhan's cell (L). Age: 17 weeks. $\times 1,200$. Bar $=10 \mu \mathrm{m}$. F: Basement membrane (arrowheads). Age: 17 weeks. $\times 1,200$. Bar $=10 \mu \mathrm{m}$. 
Plate III
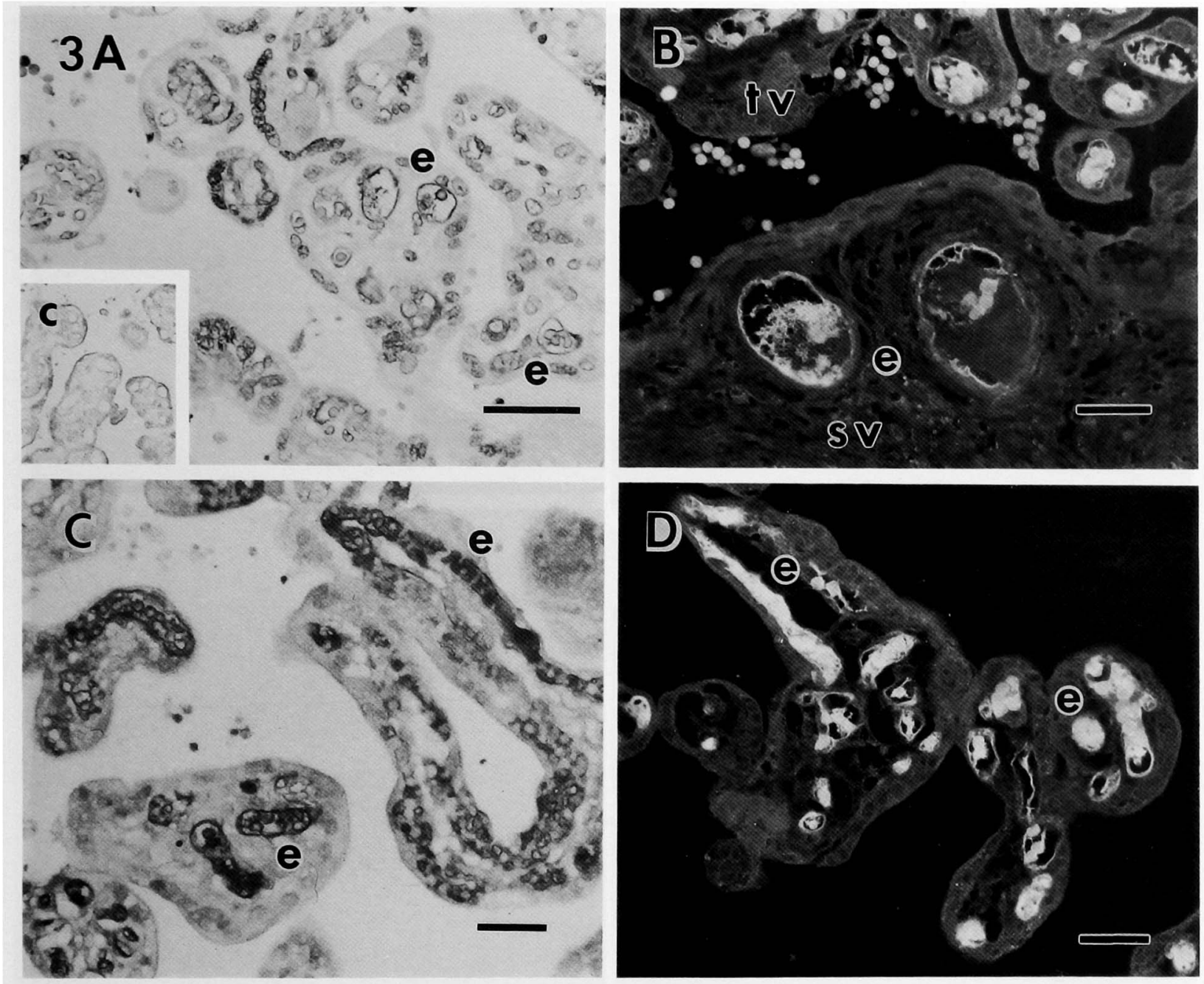

\section{Plate III}

Fig. 3. Immunocytochemical staining of the villi at term. A: Foetal blood vesseles including endothelial cells (e). Age; 37 weeks and 1 day. $\times 300$. Mayer's Haematoxylin counterstain. Bar $=50 \mu \mathrm{m}$; Negative control (c). Age: 39 weeks. $\times 220$. Methyl Green counterstain. B: Foetal endothelial cells (e) of the tertiary stem villi (sv) and terminal villi (tv). Age: 37 weeks and 1 day. $\times 600$. Bar $=20 \mu \mathrm{m}$. C: Foetal endothelial cells (e). Age: 37 weeks and day. $\times 600$. Methyl Green counterstain. Bar $=20 \mu \mathrm{m}$. D: Foetal endothelial cells (e) of the terminal villi. Age: 37 weeks and 1 day. $\times 600$. Bar $=20 \mu \mathrm{m}$ 